\title{
THE RELATION BETWEEN THE LANDSCAPE DESIGN AND BRAND IMAGE IN PURCHASE PREFERENCES OF TOURISTS: THE CASE OF SAFRANBOLU AND NEVŞEHIR, IN TURKEY
}

\author{
DÖNMEZ, Y. ${ }^{*}-$ TÜRKMEN, $F^{2}$ \\ ${ }^{1}$ Karabük University, Faculty of Forestry \\ Department of Landscape Architecture, Karabük, Turkey \\ ${ }^{2}$ Khoja Akhmet Yassawi International Kazakh-Turkish University \\ Faculty of Social Sciences, Department of Tourism Management, Turkistan, Kazakhstan \\ (phone: +90-5-465-030-339) \\ *Corresponding author \\ e-mail: yasindonmez@karabuk.edu.tr \\ (Received 20 $0^{\text {th }}$ Sep 2017; accepted $18^{\text {th }}$ Dec 2017)
}

\begin{abstract}
With the developments in the tourism sector, the preferences and demands of tourists are handled with more care. Parallel to this, the tourism businesses that host tourists are in constant search for innovation. The aim of this study is to investigate the relation between the landscape design works and the brand image in the purchase preferences of the tourists in accommodation businesses; and to reveal the relation between these two factors by obtaining the demographical information of the tourists visiting Safranbolu and Nevşehir destinations. The Questionnaire Technique was made use of in this study. The percentage and frequency distributions are given. The Pearson Correlation Analysis was used in order to determine the relation between the landscape design works and the brand image in the preferences of tourists in accommodation businesses. As a result, it was determined that as the role of personal area regulations increase in the purchase preferences of tourists, so do the brand awareness and associations, brand image, quality perceptions, and brand trust.
\end{abstract}

Keywords: brand, image, landscape, accommodation businesses, purchase

\section{Introduction}

Many factors including demographical, economic, and socio-cultural ones, and the facilities provided by tourism businesses in the tourism sector play important roles in the purchase preferences of the tourists. In addition, some attractive characteristics of the destination also have important effects on the selection of the destinations by tourists (Correia and Pimpao, 2008; Demir, 2010). For this reason, the attractive factors of a destination are important because they provide advantage for that specific destination to be preferred among the other destinations. The brand image, physical structures of the tourism businesses and the services they provide are important in making the destinations be perceived as different from the other ones.

The spatial properties of touristic areas are influential on the purchase preferences of tourists, which are considered as being important by tourism businesses. Purchase decision-making process is a study field that is emphasized and studied much in tourism sector. The purchase decision of tourists, their decisions before the travel, their experiences, their evaluations on their experiences and their intentions after the purchase are important for tourism businesses. The purchase decision in tourism services means the starting point of a complex process. While the decision given to purchase a product is the sole factor in purchase decision-making process, the purchase 
decision of a tourist includes many other factors related with their travels. One single decision of the tourists on their travels will trigger their other decisions. In other words, tourists have to make many decisions on the products and services they will purchase in their travels. In general, it is accepted that the decision-making process of a consumer consists of 5 basic steps (Filiatrault and Ritchie, 1980; Solomon, 2004; Chen and Tsai, 2007; Hyde, 2008; Smallman and Moore, 2010; Yüncü and Kozak, 2010). These steps are as follows;

- Determining the problem,

- Searching for information,

- Evaluation of the alternatives,

- Purchase decision / preference

- The behavior after the purchase

Although the brand value refers to the whole of the assets owned by a brand, the components of a brand consist of the awareness on the brand, being influenced by the brand, trust in the brand, the associations about the brand, the brand image, and the devotion to the brand elements. The reason of testing the effect of all the components of brand value on the devotion to the brand is that this devotion is considered as one of the most important components in establishing and sustaining long-term relations with the customers. Although brand image was recognized as the driving force of brand asset and brand performance, few studies have elaborated on the relationship between brand image and brand equity (Morrison, 1989; Torlak et al., 2014; Zhang, 2015).

The brand image consists of the whole of the positive or negative, emotional or aesthetical impressions created by a product in the target market. In other words, it may be considered as the whole of the emotional and rational evaluations of a person on a product or service. Based on these definitions, it is possible to claim that the Brand Image is created in the minds as a result of the perceptions of the consumers about a product or a service and as a result of the marketing efforts of the brand. In other words, consumers may have an image in their minds with the help of the associations about a brand. In one sense, the attitude of the consumers towards a product may create the Brand Image. A positive brand image affects the brand loyalty and ensures the loyalty of the consumers (Ker, 1998; Peltekoğlu, 2007; Özdemir, 2009; Başgöze and Kazanc1, 2014; Baloglu et al., 2014).

There have been some changes in the purchase preferences of tourists in recent years, and the importance of the outdoor areas has come to the forefront. The design concepts in outdoor areas and relevant projects and practices that change every year are presented for the liking of the tourists. The landscape design works by landscape architects are among the first and most important factors in the preferences of tourists (Avan, 2010; Dönmez and Türkmen, 2015).

The purpose of this study is to investigate the relation between the Landscape Design and Brand Image in the Purchase Preferences of Tourists. Questionnaires were applied to the tourists visiting important tourism destinations like Safranbolu and Nevşehir.

\section{Material and Methods}

In this study, in which the viewpoints of tourists on the effects of landscape design on purchase preferences in accommodation businesses were analyzed; an answer was sought for the question "Is there a relation between the landscape design and brand 
image in the preferences of the tourists for accommodation?" The study population consisted of the tourists who visited the hotels in Nevşehir and Safranbolu (Fig. 1) between June and April, 2016-2017. Safranbolu and Nevşehir cities are important tourist destinations of Turkey because of their natural and cultural features, and they are visited by more than one million local and foreign tourists a year.

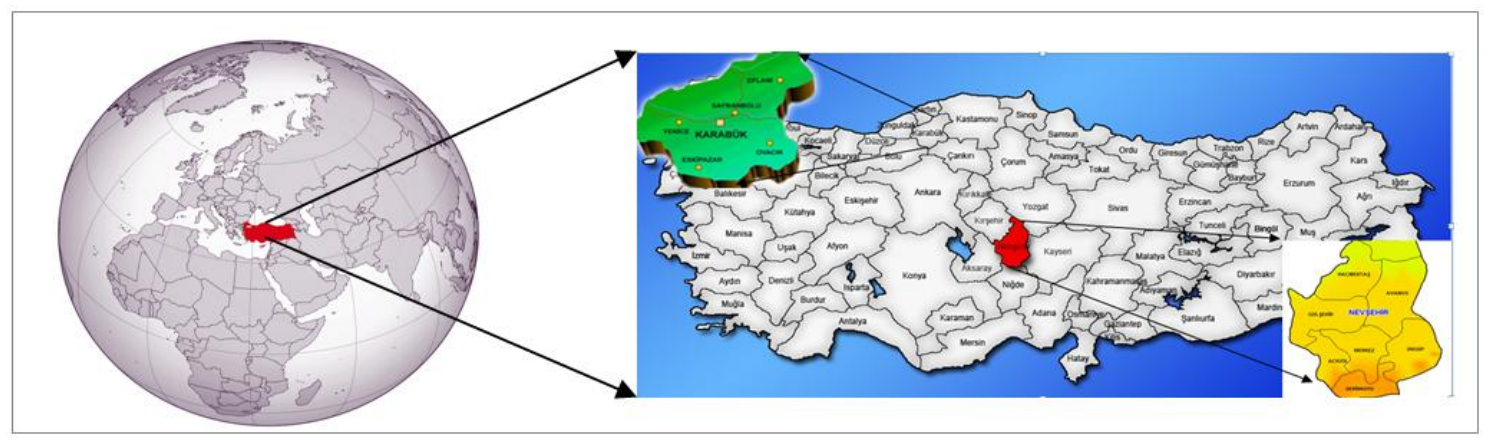

Figure 1. Location of Research Areas in the World and Turkey

In determining the sampling that represent the features of the study population, the Convenient Sampling Method was used. The total number of the tourists coming to

Nevşehir and Safranbolu was determined as 2,250,000, and the $\mathrm{n}=\mathrm{NPq} /(\mathrm{N}-1) \mathrm{B}^{2}+\mathrm{Pq} /$ $\mathrm{Z}^{2}$ Model, which was developed by Ryan (1995) was used to determine the sampling size.

$$
n=N P q /(N-1) B^{2}+P q / Z
$$

According to the formula:

$\mathbf{n}=$ Sampling number,

$\mathbf{N}=$ The study population,

$\mathbf{P}=$ The rate or estimation of the population,

$\mathbf{q}=1-\mathrm{P}$,

$\mathbf{B}=$ Bearable error rate,

$\mathbf{Z}=$ Desired confidence interval.

In this respect; since $\mathrm{N}=2,250,000$ tourists, $\mathrm{P}=0.5, \mathrm{q}=0.5, \mathrm{~B}=0.05, \mathrm{Z}=1.96, \mathrm{n}=$ $2,250,000(0.5)(0.5) /(2,250,000-1)(0.05)^{2}+(0.5)(0.5) /(1.96)^{2} ; \mathrm{n}=384$ tourists were determined.

The Questionnaire Technique was used in the study. The Questionnaire form consisted of three parts. In the first part, seven questions were asked to determine the demographical properties of the participants. There were seventeen questions, which were prepared by receiving specialist viewpoints and with a literature review on landscape design in the second part. In the last part, there were 42 statements about the Brand Image. The statements in the second and third parts were assessed with 5-Point Likert-type scale ranging through "I do not agree et all" and "I completely agree". This Questionnaire Form was copied as 750 forms and applied in the target population. After the Questionnaires with missing or invalid parts were eliminated, 511 Questionnaires were included in the study. 
The data were analyzed in the SPSS 23 (Statistical Package for the Social Sciences 23) software. The Factor Analysis was applied to the data by using the Varimax Rotation and Principal Components Methods. The applicability of the Factor Analysis was checked with the Bartlett Test, and the adequacy of the sampling size was checked with the Kaiser-MePlace-Olkin (KMO) value. The Cronbach's Alpha values were calculated for the internal consistency of the scale and for Reliability Analysis. After the percentage and frequency values were given about the demographical values of the participants, the Pearson Correlation Analysis was made use of to determine the relation between the landscape design and brand image in the preferences of the tourists for accommodation businesses.

\section{Results}

The Factor Analysis results on the viewpoints of the tourists about the role of the landscape design works in purchase preferences are given in Table 1. According to these results, the Kaiser-MePlace-Olkin value gave the sampling size adequacy as $\mathrm{KMO}=0.833$; and the Bartlett Test gave the applicability of the Factor Analysis as $\chi^{2}$ $=3407.132 ; \mathrm{p}<0.001$. In addition, out of the 4 factors, which explained $23.204 \%$ of the total variance, the "Entertaining Area Organizations" sub-dimension was the first factor, the "Compulsory Area Organizations" sub-dimension was the second factor explaining $18.135 \%$ of the total variance; "Green Area Organizations" sub-dimension was the third factor explaining $13.916 \%$ of the total variance; and as the last item, the "Personal Area Organizations" sub-dimension was the fourth factor explaining $10.342 \%$ of the total variance. Again, according to the findings in Table 1, the General Reliability Coefficient (Cronbach's Alpha) of the scale, which involved the viewpoints of the tourists on the landscape design works in their purchase preferences, was calculated as $\alpha=0.869$. Kayıs, 2009 considered the ranges where Reliability (Cronbach's Alpha) Coefficient values would be and accepted that if the reliability was " $0.6 \leq \alpha<0.80$ ", the Scale would be extremely reliable; and if it was " $0.80 \leq \alpha<1.00$ ", the scale would be highly reliable. For this reason, it is possible to say that the scale is highly reliable.

Table 1. The Factor Analysis Made on the Statements of the Tourists about the Role of Landscape Design on the Purchase Preferences

\begin{tabular}{|c|c|c|c|c|}
\hline Statements & 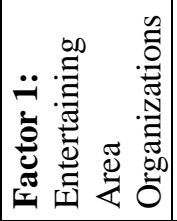 & 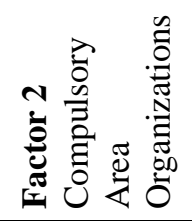 & 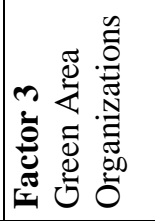 & 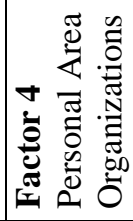 \\
\hline 1. There must be a swimming pool. & 0.860 & & & \\
\hline $\begin{array}{l}\text { 2. There must be swimming pools designed } \\
\text { specifically for children. }\end{array}$ & 0.720 & & & \\
\hline 3. There must be playgrounds for children. & & 0.806 & & \\
\hline 4. There must be recreational areas. & & 0.543 & & \\
\hline 5. There must be Open/Closed car parks. & & 0.786 & & \\
\hline 6. There must be a Botanical Garden. & & & 0.810 & \\
\hline 7. There must be trekking areas. & & & 0.682 & \\
\hline $\begin{array}{l}\text { 8. There must be vegetation design in different } \\
\text { forms. }\end{array}$ & & & 0.852 & \\
\hline 9. There must be designs with plenty of flowers. & & & 0.853 & \\
\hline
\end{tabular}




\begin{tabular}{|c|c|c|c|c|}
\hline 10. The grass areas must be bigger. & & & 0783 & \\
\hline $\begin{array}{l}\text { 11. There must be different designs in accordance } \\
\text { with the structure of the area. }\end{array}$ & & & & 0.615 \\
\hline $\begin{array}{l}\text { 12. There must be recreational water elements like } \\
\text { ornamental pool and waterfall. }\end{array}$ & & & & 0.687 \\
\hline $\begin{array}{l}\text { 13. There must be sales stand for regional } \\
\text { products. }\end{array}$ & & & & 0.596 \\
\hline $\begin{array}{l}\text { 14. There must be amphitheaters for concerts or } \\
\text { other activities. }\end{array}$ & & & & 0.675 \\
\hline $\begin{array}{l}\text { 15. The night lighting in the garden must be in } \\
\text { different color and design. }\end{array}$ & & & & 0.703 \\
\hline$\overline{\mathrm{X}} / \mathbf{s d}$ & 4.18/1.00 & $4.20 / 0.87$ & $3.75 / 1.02$ & $3.99 / 0.77$ \\
\hline Eigenvalues & 3.481 & 2.720 & 2.087 & 1.551 \\
\hline Variance Explanation Rate & 23.204 & 18.135 & 13.916 & 10.342 \\
\hline Cumulative Variance & 23.204 & 41.340 & 55.256 & 65.597 \\
\hline $\begin{array}{l}\begin{array}{l}\text { Sub-Dimension } \\
\text { Alpha) }\end{array} \\
\end{array}$ & 0.701 & 0.675 & 0.893 & 0.757 \\
\hline General Scale Reliability (Cronbach's Alpha) & & 0.869 & & \\
\hline
\end{tabular}

Kaiser-MePlace-Olkin $($ KMO $)=0.833$

Bartlett test: $\chi^{2}=3407.132 ; p=0.000$

When the reliability coefficients of the sub-dimensions of the landscape design were analyzed, similarly, it was seen thet all the dimensions had Reliability Coefficients (Cronbach's Alpha) higher than 0.6. The Reliability Coefficient of the Entertaining Area Organizations dimension was found to be 0.70; the Reliability Coefficient of the Compulsory Area Organizations dimension was found to be 0.68 ; the Reliability Coefficient of the Green Area Organizations dimension was found to be 0.89; and the Reliability Coefficient of the Personal Area Organizations dimension was found to be 0.76 .

The Factor Analysis results on the statements that reveal the viewpoints of tourists about the effects of the brand image on purchase preferences are given in Table 2. According to these results, the Kaiser-MePlace-Olkin value gave the adequacy of the sampling volume as $\mathrm{KMO}=0.906$; the Bartlett Test gave the applicability of the Factor Analysis as $\chi^{2}=14816.096 ; \mathrm{p}<0.001$. In addition, the "Brand Awareness and Associations" sub-dimension, which explains $12.541 \%$ of the total variance out of the 8 Factors that constitute the scale, is the first factor; the "Brand Image" sub-dimension is the second factor that explains $11.760 \%$ of the total variance; the "Perceived Quality" sub-dimension is the third factor that explains $10.378 \%$ of the total variance; the "Brand Trust" sub-dimension is the fourth factor explaining $9.212 \%$ of the total variance; the "Brand Loyalty" sub-dimension is the fifth factor explaining $8.147 \%$ of the total variance; the "Brand Purchase" sub-dimension is the sixth factor explaining $7.123 \%$ of the total variance; the "Brand Attitude" sub-dimension is the seventh factor explaining $5.009 \%$ of the total variance; and as the last item, the "Perceived Risk of the Brand" sub-dimension is the eighth factor explaining $2.807 \%$ of the total variance. Again, according to the findings given in Table 2, the General Reliability Coefficient (Cronbach's Alpha) of the scale that investigated the role of the brand image in purchase preferences of the tourists was calculated as $\alpha=0.95$. For this reason, it is possible to claim that the scale is highly reliable. 
Table 2. The Factor Analysis on the Statements of the Tourists on Purchase Preferences and Brand Image

\begin{tabular}{|c|c|c|c|c|c|c|c|c|}
\hline Statements & 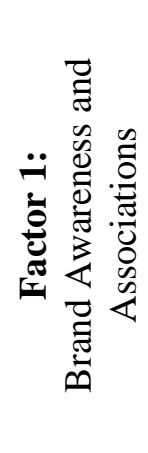 & 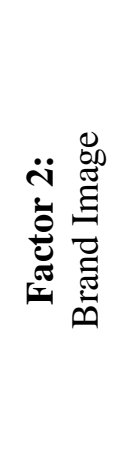 & 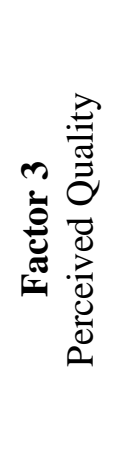 & 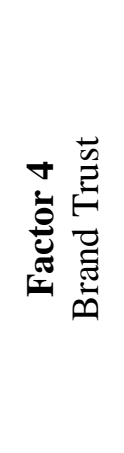 & 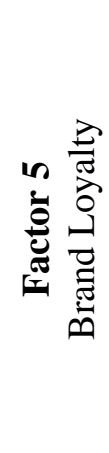 & 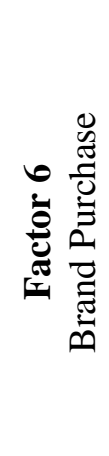 & 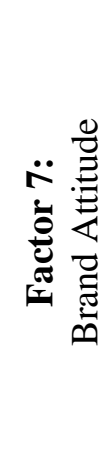 & 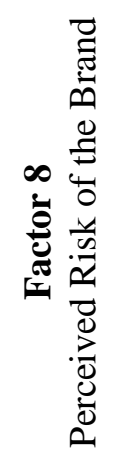 \\
\hline $\begin{array}{l}\text { 1. I know the architectural structure of this hotel. } \\
\text { 2. I am aware of the brand name of this hotel. } \\
\text { 3. I differentiate this hotel from the other brand hotels. } \\
\text { 4. Some characteristics of this hotel cross my mind } \\
\text { immediately when I hear its name. } \\
\text { 5. I immediately remember the symbol or logo of this } \\
\text { hotel. } \\
\text { 6. When I want to make a reservation at a hotel business, I } \\
\text { firstly remember the name of this hotel. } \\
\text { 7. This hotel is comfortable. } \\
\text { 8. The service presentation is at a high level in this hotel. } \\
\text { 9. This hotel has a very good image. } \\
\text { 10. This hotel is a luxurious one. } \\
\text { 11. This hotel is suitable for people from upper class. } \\
\text { 12. I feel special when I arrive at this hotel. } \\
\text { 13. The service in this hotel is beyond my expectations. } \\
\text { 14. This hotel has a long history. } \\
\text { 15. This hotel belongs to a good brand. }\end{array}$ & $\begin{array}{l}0.593 \\
0.735 \\
0.733 \\
0.651 \\
0.710 \\
0.604\end{array}$ & $\begin{array}{l}0.521 \\
0.531 \\
0.644 \\
0.642 \\
0.589 \\
0.480 \\
0.572 \\
0.666 \\
0.513\end{array}$ & & & & & & \\
\hline
\end{tabular}


16. The employees of this hotel make me feel that I am a special and precious guest.

17. This hotel has modern equipment.

18. The employees of this hotel are clean and elegant.

19. The employees who are specialists in their fields work in this hotel.

20. This hotel provides the correct service at the correct time.

21. The employees of this hotel solve the problems of the guests in a fast manner.

22. The employees of this hotel establish efficient communication with guests.

23. This food and beverage of this hotel are quality.

24. The brand of this hotel gives me trust.

25 . This hotel provides the service quality it promises.

26. This hotel is consistent and continuous in its service quality.

27. Everything the brand of this hotel refers is in agreement with each other (price. quality, advertisement, variety, etc.).

28. I am happy to have been accommodated in this hotel.

29. When I compare this hotel with the others this is my first choice.

30. I consider myself as a loyal guest of this hotel.

31. I recommend this hotel to my friends.

32. I do not change this hotel even if the other hotels make promotions.

33. I have the intention of coming to this hotel again.

34. I will come to this hotel again in the future.

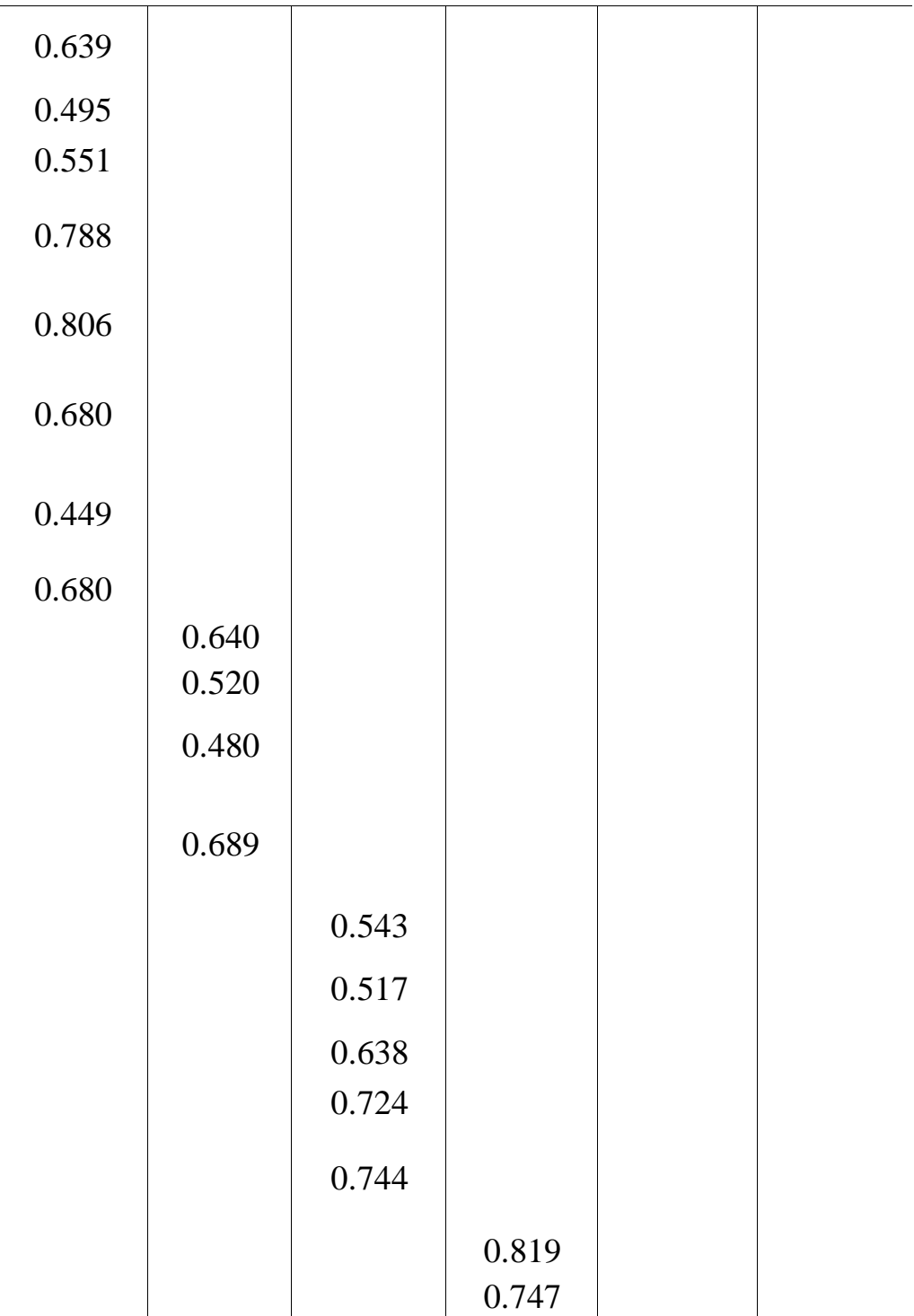




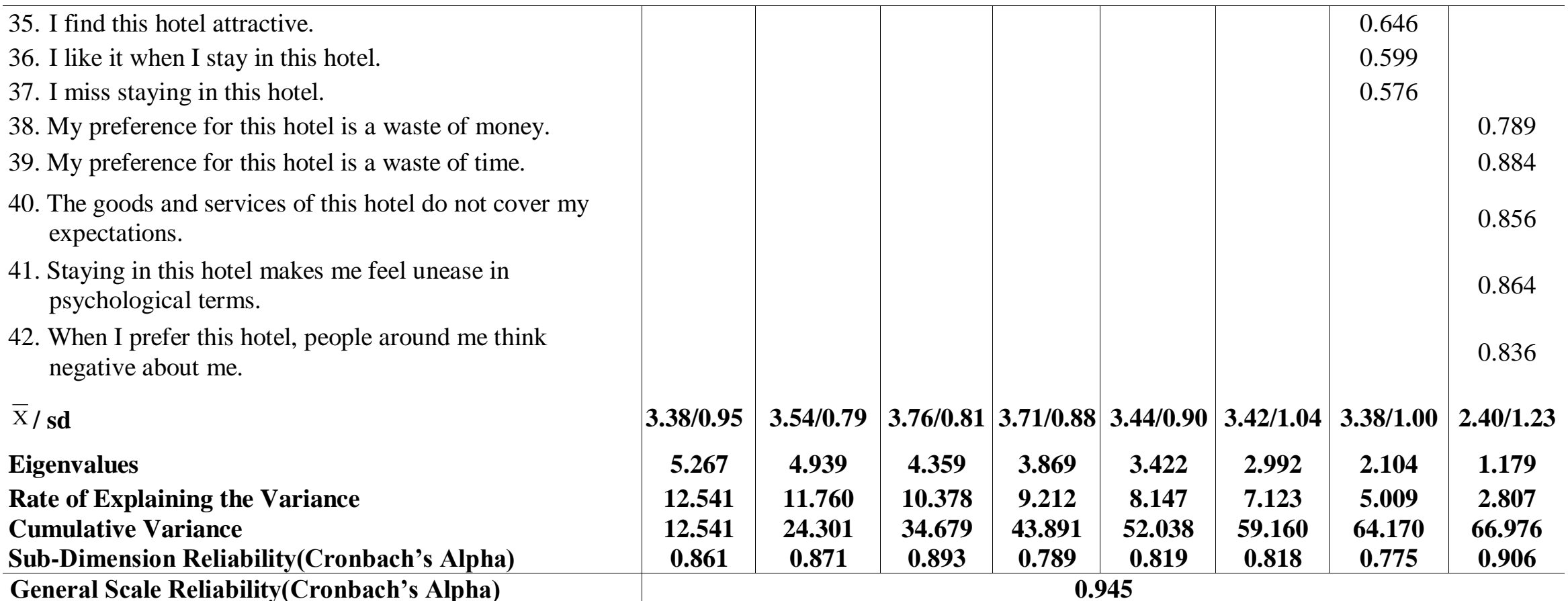

Kaiser-MePlace-Olkin $(K M O)=0.906$

Bartlett test: $\chi^{2}=14816.096 ; p=0.000$ 
Similarly, when the reliability coefficients in the sub-dimensions of the Brand Image were analyzed it was seen thet all the Reliability Coefficients (Cronbach's Alpha) were bigger than 0.6 and highly reliable. The Reliability Coefficient of the Brand Awareness and Associations dimension was 0.86; the Reliability Coefficient of the Brand Image Sub-Dimension was 0.87; the Reliability Coefficient of the Perceived Quality dimension was 0.89; the Reliability Coefficient of the Brand Trust Sub-dimension was 0.79; the Reliability Coefficient of the Brand Loyalty Sub-dimension was 0.82; the Reliability Coefficient of the Brand Purchase dimension was 0.82; the Reliability Coefficient of the Brand Attitude dimension was 0.78; and the Reliability Coefficient of the Perceived Risk of the Brand dimension was 0.91.

The demographical and personal properties of 511 tourists who participated in the study are given in Table 3. In this context, 59.5\% ( $\mathrm{f}=304)$ of the tourists who participated in the study had touristic activities in Nevşehir, 40.5\% ( $\mathrm{f}=207)$ of the tourists who participated in the study had touristic activities in Safranbolu. It was determined that $45 \%(\mathrm{f}=230)$ of the participants were local tourists, and $55 \%(\mathrm{f}=281)$ of them were foreign tourists.

Table 3. Frequency and Percentage Distributions of the Demographical Properties of the Participants $(n=511)$

\begin{tabular}{c|c|c|c}
\hline Variables & Groups & f & \% \\
\hline \multirow{2}{*}{ Place } & Nevşehir & 304 & 59.5 \\
& Safranbolu & 207 & 40.5 \\
Gender & Women & 300 & 58.7 \\
& Men & 211 & 41.3 \\
Age & $20 \leq$ & 67 & 13.1 \\
& $21-30$ & 91 & 17.8 \\
& $31-40$ & 234 & 45.8 \\
Marital Status & $41-50$ & 76 & 14.9 \\
& $51 \geq$ & 43 & 8.4 \\
& Married & 339 & 66.3 \\
Education & Single & 172 & 33.7 \\
& Primary School & 36 & 7.0 \\
& High School & 81 & 15.9 \\
Nationality & 2-Year Degree & 35 & 6.8 \\
& Undergraduate Degree & 268 & 52.4 \\
& Postgraduate Degree & 91 & 17.8 \\
Profession & Local & 230 & 45.0 \\
& Foreign & 281 & 55.0 \\
& Self-Employed & 129 & 25.2 \\
& Public Employee & 130 & 25.4 \\
& Retired & 60 & 11.7 \\
& Private Sector Employee & 192 & 37.6 \\
& 1000TL $\leq$ & 17 & 3.3 \\
& 1001-2000TL & 18 & 3.5 \\
& 2001-3000TL & 72 & 14.1 \\
& 3001-4000TL & 187 & 36.6 \\
& 4001-5000TL & 150 & 29.4 \\
& 5001TL $\geq$ & 67 & 13.1 \\
\hline & &
\end{tabular}


When the statistical values of the demographical properties of the participants were analyzed it was seen that $58.7 \%(\mathrm{f}=300)$ were women, $41.3 \%(\mathrm{f}=211)$ were men. When the age distributions of the participants were analyzed it was seen that $45.8 \%(\mathrm{f}=234)$ of the tourists were between 31-40 years of age. Those between 21-30 years of age followed this with $17.8 \%(\mathrm{f}=91)$. The rate of the participants between 41-50 years of age was $14.9 \%(\mathrm{f}=76)$; and the rate of those at and below the age of 20 was $13.1 \%$ $(\mathrm{f}=67)$; and the rate of those who were at and above the age of 51 was $8.4 \%(\mathrm{f}=43)$. In addition, the majority of the tourists who were included in the study $(66.3 \% ; \mathrm{f}=339)$ were married, while $33.7 \%$ ( $\mathrm{f}=172$ ) were single.

When the distribution of the participants in term of educational status was analyzed it was determined that the majority had Undergraduate Degrees $(52.4 \% ; \mathrm{f}=268)$ and $17.8 \%(\mathrm{f}=91)$ of them had postgraduate degrees. This situation is the proof that the culture level of the participants is very high. High School graduates follow these rates with $15.9 \%(\mathrm{f}=81)$; Primary School graduates with 7\% $(\mathrm{f}=36)$ and 2-Year Degree graduates with a rate of $6.8 \%(\mathrm{f}=35)$.

When the professional groups of the tourists who were included in the study were analyzed it was determined that $37.6 \%(\mathrm{f}=192)$ worked at private sector, $25.4 \%(\mathrm{f}=130)$ worked at public sector; $25.2 \%$ ( $\mathrm{f}=129$ ) were self-employed; and $11.7 \%$ ( $\mathrm{f}=60)$ were retired. As the last item, the income levels of the participants were analyzed and it was determined that the majority of them had a monthly income of 3001 and 5000 TL (Total 66\%; $\mathrm{f}=337$ ). The percentage of those with $2000 \mathrm{TL}$ and below income was determined as $6.8 \%(\mathrm{f}=35)$. Only $13.1 \%(\mathrm{f}=67)$ of the participants had a monthly income at and over $5001 \mathrm{TL}$.

In calculating the income levels of the foreign tourists, the participants were asked to respond with a currency of the country where they lived, and then this amount was converted into Turkish Liras over the exchange rate of then-present conditions.

As it is seen in Table 4, the level of the relation between the sub-dimensions of the Role of Landscape Design Works and Brand Image in the Purchase Preferences of the tourists was tested by applying Correlation Analysis. In this context, the level of the relation between the variables was defined as "Very Weak" when the Pearson Correlation Coefficient was below 0.19; "Weak" when the Coefficient was 0.20-0.39; "Medium Level" when Coefficient was 0.40-0.59; "Strong" when Coefficient was 0.600.79; and "Very Strong" when Coefficient was 0.80-1.00 (Ural and Kılıç, 2005).

When the sub-dimensions of the Entertaining Area Organizations, which is one of the sub-dimensions of Landscape Design Works, and the Brand Image were compared, it was seen that there was a weak and positive relation between the four dimensions that constituted the Brand Image and Purchase Preferences on Entertaining Area Organizations. In this context, as the role of the Entertaining Area Organizations increase in the Purchase Preferences of the tourists, the Brand Awareness and Associations $(r=0.252)$, Brand Image $(r=0.175)$, Quality Perceptions $(r=0.129)$ and Brand Trust $(r=0.105)$ increase in a linear manner. No significant relations were detected between the role of Preferences Entertaining Area Organizations in Purchase Preferences of the tourists and the other four dimensions that constituted the Brand Image. 
Table 4. The Comparison of the Relation between the Role of Landscape Design Works in Purchase Preferences of the Tourists and the Subdimensions of the Brand Image (Correlation Analysis)

\begin{tabular}{|c|c|c|c|c|c|c|c|c|c|c|c|c|c|}
\hline $\begin{array}{l}\text { Brand } \\
\text { Design of Landscape } \\
\text { Dorks }\end{array}$ & lage & 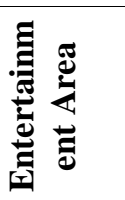 & 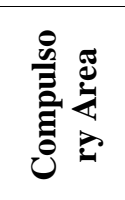 & 焉 & 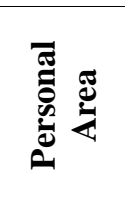 & 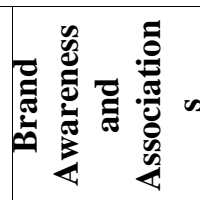 & 离 & 递苛 & 预 & 司 & 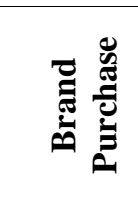 & 兽 & 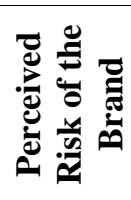 \\
\hline \multirow[t]{2}{*}{ Entertainment Area } & $\mathrm{r}$ & \multirow[b]{2}{*}{1} & 0.465 & 0.215 & 0.343 & 0.252 & 0.175 & 0.129 & 0.105 & 0.065 & 0.030 & 0.004 & -0.030 \\
\hline & $\mathrm{p}$ & & $0.000^{* *}$ & $0.000^{* * *}$ & $0.000^{* * *}$ & $\mathbf{0 . 0 0 0}^{* * *}$ & $0.000^{* * *}$ & $\mathbf{0 . 0 0 3}^{* * *}$ & $0.018^{*}$ & 0.142 & 0.501 & 0.930 & 0.498 \\
\hline \multirow[t]{2}{*}{ Compulsory Area } & $\mathrm{r}$ & 0.465 & \multirow[b]{2}{*}{1} & 0.326 & 0.433 & 0.160 & 0.118 & 0.070 & 0.102 & -0.027 & -0.024 & -0.042 & -0.133 \\
\hline & $\mathrm{p}$ & $0.000^{* * *}$ & & $0.000^{* * *}$ & $0.000^{* * *}$ & $0.000^{* * *}$ & $0.008^{* * *}$ & 0.115 & $0.021^{*}$ & 0.539 & 0.596 & 0.344 & $0.003^{* * *}$ \\
\hline \multirow[t]{2}{*}{ Green Area } & $\mathrm{r}$ & 0.215 & 0.326 & \multirow[b]{2}{*}{1} & 0.522 & 0.128 & 0.060 & -0.056 & 0.041 & -0.040 & -0.017 & -0.029 & 0.035 \\
\hline & $\mathrm{p}$ & $0.000^{* * *}$ & $0.000^{* * *}$ & & $0.000^{* * *}$ & $0.004^{3 * 4}$ & 0.179 & 0.203 & 0.355 & 0.363 & 0.696 & 0.520 & 0.436 \\
\hline \multirow[t]{2}{*}{ Personal Area } & $\mathrm{r}$ & 0.343 & 0.433 & 0.522 & \multirow[t]{2}{*}{ 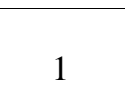 } & 0.323 & 0.175 & 0.180 & 0.165 & 0.016 & -0.026 & -0.054 & -0.156 \\
\hline & $\mathrm{p}$ & $0.000^{* *}$ & $0.000^{* *}$ & $0.000^{* *}$ & & $0.000^{* * *}$ & $0.000^{* *}$ & $0.000^{* *}$ & $0.000^{* *}$ & 0.713 & 0.559 & 0.222 & $0.000^{* *}$ \\
\hline \multirow{2}{*}{$\begin{array}{c}\text { Brand Awareness and } \\
\text { Associations } \\
\end{array}$} & $\mathrm{r}$ & 0.252 & 0.160 & 0.128 & 0.323 & \multirow[t]{2}{*}{ 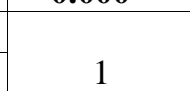 } & 0.739 & 0.628 & 0.527 & 0.444 & 0.410 & 0.358 & 0.005 \\
\hline & $\mathrm{p}$ & $0.000^{* * *}$ & $0.000^{* * *}$ & $0.004^{* * *}$ & $0.000^{* * *}$ & & $0.000^{* * *}$ & $0.000^{* * *}$ & $0.000^{* *}$ & $0.000^{* * *}$ & $0.000^{* * *}$ & $0.000^{* * *}$ & 0.907 \\
\hline \multirow{2}{*}{ Brand Image } & $\mathrm{r}$ & 0.175 & 0.118 & 0.060 & 0.175 & 0.739 & \multirow[b]{2}{*}{1} & 0.772 & 0.644 & 0.606 & 0.552 & 0.558 & 0.058 \\
\hline & $\mathrm{p}$ & $0.000^{* * *}$ & $\mathbf{0 . 0 0 8}^{* * *}$ & 0.179 & $0.000^{* * *}$ & $0.000^{* * *}$ & & $0.000^{* * *}$ & $0.000^{* * *}$ & $0.000^{* * *}$ & $0.000^{* * *}$ & $0.000^{* * *}$ & 0.189 \\
\hline \multirow{2}{*}{ Perceived Quality } & $\mathrm{r}$ & 0.129 & 0.070 & -0.056 & 0.180 & 0.628 & 0.772 & \multirow[t]{2}{*}{ 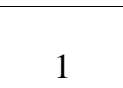 } & 0.704 & 0.515 & 0.451 & 0.462 & -0.023 \\
\hline & $\mathrm{p}$ & $\mathrm{0.003}^{* *}$ & 0.115 & 0.203 & $0.000^{* * *}$ & $\mathbf{0 . 0 0 0}^{* *}$ & $0.000^{* *}$ & & $0.000^{* *}$ & $\mathbf{0 . 0 0 0}^{* * *}$ & $0.000^{* *}$ & $0.000^{* *}$ & 0.597 \\
\hline \multirow{2}{*}{ Brand Trust } & $\mathrm{r}$ & 0.105 & 0.102 & 0.041 & 0.165 & 0.527 & 0.644 & 0.704 & \multirow[b]{2}{*}{1} & 0.565 & 0.446 & 0.512 & 0.018 \\
\hline & $\mathrm{p}$ & $0.018^{*}$ & $0.021^{*}$ & 0.355 & $0.000^{* * *}$ & $\mathbf{0 . 0 0 0}^{* * *}$ & $0.000^{* * *}$ & $0.000^{* * *}$ & & $0.000^{* * *}$ & $0.000^{* * *}$ & $0.000^{* * *}$ & 0.679 \\
\hline \multirow{2}{*}{ Brand Loyalty } & $\mathrm{r}$ & 0.065 & -0.027 & -0.040 & 0.016 & 0.444 & 0.606 & 0.515 & 0.565 & \multirow[b]{2}{*}{1} & 0.713 & 0.695 & 0.184 \\
\hline & $\mathrm{p}$ & 0.142 & 0.539 & 0.363 & 0.713 & $0.000^{* * *}$ & $0.000^{* * *}$ & $0.000^{* *}$ & $0.000^{* *}$ & & $0.000^{* *}$ & $0.000^{* *}$ & $0.000^{* * *}$ \\
\hline \multirow{2}{*}{ Brand Purchase } & $\mathrm{r}$ & 0.030 & -0.024 & -0.017 & -0.026 & 0.410 & 0.552 & 0.451 & 0.446 & 0.713 & \multirow[b]{2}{*}{1} & 0.744 & 0.176 \\
\hline & $\mathrm{p}$ & 0.501 & 0.596 & 0.696 & 0.559 & $0.000^{* * *}$ & $0.000^{* * *}$ & $0.000^{* * *}$ & $0.000^{* *}$ & $0.000^{* * *}$ & & $0.000^{* * *}$ & $0.000^{* * *}$ \\
\hline \multirow[t]{2}{*}{ Brand Attitude } & $\mathrm{r}$ & 0.004 & -0.042 & -0.029 & -0.054 & 0.358 & 0.558 & 0.462 & 0.512 & 0.695 & 0.744 & \multirow[b]{2}{*}{1} & 0.204 \\
\hline & $\mathrm{p}$ & 0.930 & 0.344 & 0.520 & 0.222 & $0.000^{* * *}$ & $0.000^{* *}$ & $0.000^{* * *}$ & $0.000^{* *}$ & $0.000^{* * *}$ & $0.000^{* * *}$ & & $0.000^{* * *}$ \\
\hline \multirow{2}{*}{$\begin{array}{l}\text { Perceived Risk of the } \\
\text { Brand }\end{array}$} & $\mathrm{r}$ & -0.030 & -0.133 & 0.035 & -0.156 & 0.005 & 0.058 & -0.023 & 0.018 & 0.184 & 0.176 & 0.204 & \multirow[b]{2}{*}{1} \\
\hline & $\mathrm{p}$ & 0.498 & $0.000^{* * *}$ & 0.436 & $0.000^{* * *}$ & 0.907 & 0.189 & 0.597 & 0.679 & $0.000^{* * *}$ & $0.000^{* * *}$ & $0.000^{* * *}$ & \\
\hline
\end{tabular}

$* * \mathrm{p}<0.01 \quad * \mathrm{p}<0.05$ 
When the Compulsory Area Organizations and the sub-dimensions of Brand Image are compared, a weak and negative relation was detected between the three dimensions that constituted the Compulsory Area Organizations and Brand Image; and a negative and opposite relation was detected with one dimension. In this context, as the role of the Compulsory Area Organizations increase in Purchase Preferences of the tourists, the perceptions on Brand Awareness and Associations ( $r=0.160)$, Brand Image $(r=0.118)$ and Brand Trust ( $r=0.102)$ increase. A negative and weak relation was detected between the Compulsory Area Organizations and Perceived Risk of the Brand $(r=-0.133)$. No significant relations were detected between the other four dimensions that constitute the Brand Image and the Compulsory Area Organizations sub-dimension.

When the relation between the Green Area Organizations and the sub-dimensions that constitute the Brand Image were analyzed, a weak and positive relation was detected in terms of only one dimension that constituted the Brand Image. As the Green Area Organizations in the Purchase Preferences of the tourists increase, the Brand Awareness and Associations $(\mathrm{r}=0.128)$ also increase parallel to this. No significant relations were detected as a result of the Correlation Analysis between the Green Area Organizations and the other seven dimensions that constituted the Brand Image.

When the relation between the Personal Area Organizations, which is the last dimension of the Landscape design works, and the sub-dimensions that constitute the Brand Image was analyzed, it was determined that there was a positive and weak relation between the four dimensions that constitute the Brand Image, and a negative relation with only one dimension. In this context, as the role of the Personal Area Organizations in Purchase Preferences of the tourists increased, the Brand Awareness and Associations ( $\mathrm{r}=0.323$ ), Brand Image ( $\mathrm{r}=0.175)$, Quality Perceptions ( $\mathrm{r}=0.180)$ and Brand Trust $(\mathrm{r}=0.165)$ increased. A negative and weak relation was detected between the Personal Area Organizations and Perceived Risk of the Brand ( $r=-0.156)$. When the coefficient obtained as a result of the Correlation Analysis and the Sigma-p values were assessed, no significant relations were detected between the Personal Area Organizations and the other three dimensions that constitute the Brand Image.

\section{Discussion}

A substantial number of studies have focused on tourist destination image, its components, and how they relate to behavioral intentions. The findings suggest that a positive destination image is a favorable competitive advantage for attracting first-time visitors as well as generating greater likelihood to revisit and recommendation after the visit. Earlier studies have tested the adaptability of the image and personality concepts, which were originally developed in other fields and disciplines, into the context of tourism (e.g. Baloglu and Brinberg, 1997; Ekinci and Hosany, 2006; Hosany et al., 2006; Baloglu et al., 2014).

Given their explicit importance to brand loyalty, positioning and destination selection (Ekinci, Sirakaya-Turk, and Baloglu, 2007; Keller, 1998; Baloglu et al., 2014), this is somewhat surprising. In addition, a recent study indicated that visitors do not use brand personality descriptors when asked to provide free-elicited responses to describe tourist destinations (Kneesel et al., 2010; Baloglu et al., 2014).

When the sub-dimensions of the Brand Image and the Entertaining Area Organizations, which is one of the sub-dimensions of Landscape design works, were compared, a positive and weak relation was detected between the Purchase Preferences 
in Entertaining Area Organizations and the four dimensions that constitute the Brand Image. In this context, it is seen that as the role of the Entertaining Area Organizations increased in the Purchase Preferences of the tourists, the Brand Awareness and Associations $(r=0.252)$, Brand Image $(r=0.175)$, Quality Perceptions $(r=0.129)$ and Brand Trust $(\mathrm{r}=0.105)$ increased in a linear manner. No significant differences were detected between the role of the Entertaining Area Organizations in the Purchase Preferences of the tourists and the other four dimensions that constitute the Brand Image.

When the sub-dimensions of the Compulsory Area Organizations and Brand Image were compared it was determined that there was a positive and weak relation between the Compulsory Area Organizations and the three dimensions that constitute the Brand Image, and a negative and weak relation was detected with only one dimension. In this context, as the role of Compulsory Area Organizations in Purchase Preferences in the tourists increased, the Brand Awareness and Associations ( $\mathrm{r}=0.160)$, Brand Image $(\mathrm{r}=0.118)$ and Brand Trust perceptions $(\mathrm{r}=0.102)$ increased. A negative and weak relation was detected between the Compulsory Area Organizations and Perceived Risk of the Brand $(\mathrm{r}=-0.133)$. No significant relations were detected between the Compulsory Area Organizations sub-dimension and the other four dimensions that constitute the Brand Image.

When the relation between the Green Area Organizations and the sub-dimensions that constitute the Brand Image was analyzed, a positive and weak relation was detected with only one single dimension that constituted the Brand Image. As the role of the Green Area Organizations in Purchase Preferences of the tourists increased, the Brand Awareness and Associations ( $\mathrm{r}=0.128)$ also increased parallel to this. No significant relations were detected between the Green Area Organizations and the other seven dimensions that constitute the Brand Image.

When the relation between the Personal Area Organizations and the sub-dimensions that constitute the Brand Image, which is the last dimension of the Landscape design works, was analyzed, a positive and weak relation was detected between the four dimensions that constitute the Brand Image; and a negative and weak relation was detected with only one dimension. In this context, as the role of the Personal Area Organizations increased in the Purchase Preferences of the tourists, the Brand Awareness and Associations ( $\mathrm{r}=0.323)$, Brand Image ( $\mathrm{r}=0.175)$, Quality Perceptions $(\mathrm{r}=0.180)$ and Brand Trust $(\mathrm{r}=0.165)$ also increased. A negative and weak relation was detected between the Personal Area Organizations and Perceived Risk of the Brand ( $r=-$ 0.156). When the coefficients obtained as a result of the Correlation Analysis and the sigma-p values were analyzed, no significant relations were detected between the Personal Area Organizations and the three dimensions that constituted the Brand Image. Right at this point, the quality perceptions of the tourists increase in businesses which care for the Landscape Area design works. However, no trust perceptions were detected for the business organizations that do not have landscape design works.

\section{Conclusions}

Countries seek ways to increase their tourism incomes by applying various encouragements in different fields. The tourism businesses, which have become a brand name in the sector, apply different regulations and organizations according to the purchase behaviors of the tourists, and try to attract the attention. For this reason, 
landscape design works are made in agreement with the desires and demands of the tourists who spend their times in outdoor environments. As it is seen in the present study, there is a significant relation between the factors that constitute the Brand Image and the landscape design works. The size of the outdoor environments owned by tourism businesses, activity areas, entertainment units, and the organizations for children are important for the Purchase Preferences of tourists.

As a conclusion, the landscape design works that will be performed in outdoor areas by tourism businesses that have become a brand name in the sector will affect the preferences of the tourists in terms of covering the targets and expectations. In this way, the occupancy rates of the tourism businesses may be increased and the stay of the tourists may be extended; and the satisfaction of the tourists will increase, and they will prefer the same business again. Thus, the tourism business, the destination and the tourists will be affected in a positive way.

\section{REFERENCES}

[1] Avan, A. (2010): Yabanc1 Turistlerin Satın Alma Karar Sürecinde Kültürel Varlıkların Etkisi: Konya Örneği. - Selçuk Üniversitesi Sosyal Bilimler Enstitüsü Dergisi, 203-219.

[2] Baloglu, S., Brinberg, D. (1997): Affective images of tourism destinations. - Journal of Travel Research 35(4): 11-15

[3] Baloglu, S., Leonard, T., Sahin, S. (2014): Destination Image and Brand Personality of Jamaica: A Model of Tourist Behavior. - Journal of Travel \& Tourism Marketing 31:8: 1057-1070. doi: 10.1080/10548408.2014.892468

[4] Başgöze, P., Kazancı, Ş. (2014): Ürün Yerleştirme ve Reklama İlişkin Tutumların Satın Alma Eğilimi ve Marka İmajı Üzerine Etkileri. - Hacettepe Üniversitesi İktisadi ve İdari Bilimler Fakültesi Dergisi 32(1).

[5] Chen, C., Tsai, D. (2007): How Destination Image and Evaluative Factors Affect Behavioral Intentions? - Tourism Management 28(4): 1115-1122.

[6] Correia, A., Pimpao, A. (2008): Decision-Making Processes of Portuguese Tourist Travelling to South America and Africa. - International Journal of Culture, Tourism and Hospitality Research 2(4): 330-373.

[7] Demir, Ş. (2010): Çekici Faktörlerin Destinasyon Seçimine Etkisi: Dalyan Örneği. - Ege Akademik Bakıș, 10(3): 1041-1054.

[8] Dönmez, Y., Türkmen, F. (2015): Role in The Purchasing Decisions of Tourists on Landscape Arrangements: Example of Belek. - Tourism Academic Journal 2(2):15-27. ISSN: 1302-5759

[9] Ekinci, Y., Hosany, S. (2006): Destination personality: An application of brand personality to tourism destinations. - Journal of Travel Research 45(2): 127-139. doi:10.1177/0047287506291603

[10] Ekinci, Y., Sirakaya-Turk, E., Baloglu, S. (2007): Host image and destination personality. - Tourism Analysis 12: 433-446. doi:10.3727/108354207783227885

[11] Filiatrault, P. Ritchie, J. R. B. (1980): Joint Purchasing Decisions: A Comparison of Influence Structure in Family and Couple Decision-Making Units. - The Journal of Consumer Research 7(2): 131-140.

[12] Hosany, S., Ekinci, Y., Uysal, M. (2006): Destination image and destination personality: An application of branding theories to tourism places. - Journal of Business Research 59: 638-642. doi:10.1016/j. jbusres.2006.01.001

[13] Hyde, K. F. (2008): Independent Traveler Decision-Making. - In: Woodside, A. G. (ed.) Advances in Culture, Tourism and Hospitality Research (Vol. 2). Bingley: JAI Press.

[14] Kayış, A. (2009): Güvenirlik Analizi. - In: Kalaycı, S. (ed.) SPSS Uygulamalı Çok Değişkenli İstatistik Teknikleri. Ankara: Asil Yayın Dağıtım. 
[15] Keller, K. L. (1998): Strategic brand management: Building, measuring and managing brand equity. - Upper Saddle River, NJ: Prentice Hall.

[16] Kneesel, E., Baloglu, S., Millar, M. (2010): Gaming destination images: Implications for branding. - Journal of Travel Research 49(1): 68-78. doi:10.1177/ 0047287509336474

[17] Ker, M. (1998): Profesyonel İmajın, İmaj Yönetimi Kapsamında Yeri ve Önemi. Pazarlama Dünyas1 12(71): 25-28.

[18] Morrison, A. M. (1989): Hospitality and Travel Marketing. - Delmar Publishers Inc., United States of America.

[19] Özdemir, H. (2009): Kurumsal Sosyal Sorumluluğun Marka İmajına Etkisi. - İstanbul Ticaret Üniversitesi Sosyal Bilimler Dergisi 8(15): 57-72.

[20] Peltekoğlu, F.B. (2007): Halkla İlişkiler Nedir? - İstanbul: Beta Yayınları.

[21] Smallman, C., Moore, K. (2010): Process Studies of Tourists' Decision-Making. - Annals of Tourism Research 37(2): 397-422.

[22] Solomon, M. R. (2004): Consumer Behavior: Buying, Having, Being. - Pearson/Prentice Hall, New Jersey.

[23] Ryan, C. (1995): Researching Tourist Satisfaction Issues, Concepts, Problems. - London: Routledge.

[24] Torlak, Ö., Doğan, V., Özkara, B. (2014): Marka Farkındalığı, Marka İmajı, Markadan Etkilenme ve Markaya Güvenin Marka Bağl1lığı Üzerindeki Görece Etkilerinin İncelenmesi: Turkcell Örneği. - Bilgi Ekonomisi ve Yönetimi Dergisi / 2014 Cilt: IX Say1: I

[25] Ural, A., Kılıç, İ. (2005): Bilimsel Araştırma Süreci ve SPSS ile Veri Analizi. - Ankara: Detay Yayınevi.

[26] Yüncü, D., Kozak, N. (2010): Türk Akademisyenlerin Kongre Tercihleri Üzerine Bir Araştırma. - Anatolia: Turizm Araştırmaları Dergisi, 21 (1): 109-120.

[27] Zhang, Y. (2015): The Impact of Brand Image on Consumer Behavior: A Literature Review. - Open Journal of Business and Management 3: 58-62. doi: 10.4236/ojbm.2015.31006. 